\title{
College Libraries and Networking
}

Networking is certainly included on virtually everyone's list of recent significant developments in librarianship. The ACRL College Libraries Section's Impact of National Library Policy and National Library Developments on the College Library Committee concurred with this view when developing an agenda of topies to pursue recently.

The impact, experienced or expected, on networks in a variety of settings-urban main libraries, research libraries, small law libraries, rural public libraries, school media centers, ete.- has already been discussed. However, only a few how-we-done-it-good articles concerning college libraries could be found.

The Committee decided the first step should be to determine what percentage of college libraries $^{1}$ belong to a network. ${ }^{2}$ The table below offers the percentage of participation and number of libraries by Carnegie category and type of control.

These results suggest a few questions which might be explored and some further analysis which might be applied.

- How much of the low participation by private Liberal Arts II colleges is due to costs and how much is attributable to a choice not to join?

- What percentage of current college cataloging is being entered into network databases? A few years ago it was estimated that $75 \%$ of all academic libraries' new acquisitions were put online.

- Would a project to enter the special collec-

This study includes those institutions in the classifications Comprehensive Universities and Colleges (I and II) and Liberal Arts Colleges (I and II) in Carnegie Commission on Higher Education, A Classification of Institutions of Higher Education (Berkeley, Calif.: The Commission, 1976). The "Standards for College Libraries," CURL News, October 1975 , p. 277 , state that colleges in these Carnegie classifications are the target institutions for the standards.

2I wish to thank Neal Kaske of the OCLC Research Department for providing me with a listing of OCLC college members by state. tions of libraries which are not in networks be feasible?

- With much attention turning toward integrated systems, is it acceptable to move on to the next generation of automation when almost onethird of college libraries have not yet joined a network?

- Are there significant variations among the percentages of participation by state or region? If so, how are fixed and prorated costs allocated in the various state and regional networks?

- What share of contributed cataloging comes from college libraries? How much is it used?

- What percentage of network-based interlibrary requests are filled by college libraries?

- What effect has the reduced HEA Title II-A grants had on college libraries' contributions to

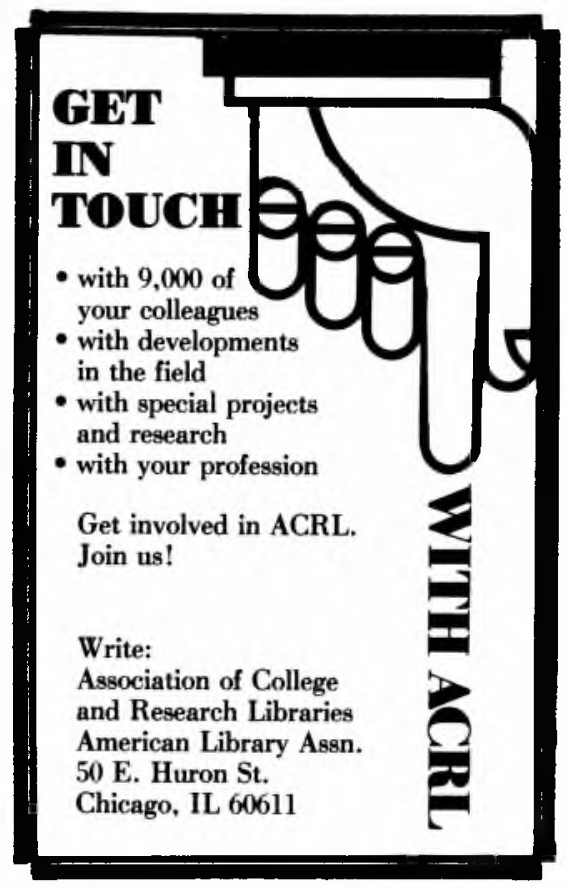

TABLE

Percentage of Participation in Nethorks AND NUMBER OF COLleGES

\begin{tabular}{|c|c|c|c|c|c|c|c|}
\hline Type of Control & I & $\begin{array}{l}\text { Comprehensive } \\
\text { II }\end{array}$ & I and II & I & $\begin{array}{c}\text { Librial Arts } \\
11\end{array}$ & I antd I] & Tortal \\
\hline Public & $87.8 \%(245)$ & $68.3 \%(101)$ & $82.1 \%(346)$ & $\mathrm{NA}(0)$ & $90.9 \%(11)$ & $90.9 \%(11)$ & $82.4 \%(357)$ \\
\hline Private & $76.6 \%(128)$ & $77.3 \%(106)$ & $76.9 \%(234)$ & $82.1 \%(123)$ & $51.3 \%(433)$ & $58.1 \%(5.56)$ & $63.7 \%(790)$ \\
\hline
\end{tabular}

Public and

Private $\quad 83.9 \%(373) \quad 72.9 \%(207) \quad 80.0 \%(580) \quad 82.1 \%(123) 52.3 \%(444) \quad 58.7 \%(567) 69.5 \%(1147)$ 
national shared catalcoing and interlibrary loan efforts? What might be the effects of zero funding?

Any group or individual interested in sharing additional information or concerns should contact the Chair of the CLS Impact Committee, John
Sheridan, Head Librarian, Transylvania University Library, Lexington, KY 40508; or the Chair of the College Libraries Section, Thomas G. Kirk, College Librarian, Berea College, Berea, KY 40404.-John Sheridan.

\section{The Exchange Experience: An American Perspective}

\author{
Larry W. Griffin \\ Interlibrary Services \\ Indiana University
}

As I have just completed eleven months at the University of Edinburgh Library as an exchange librarian from Indiana University Libraries, a number of librarians have asked me about my experience. In this report I will comment on some aspects of the exchange program that may be useful to other American librarians who are planning a similar experience in a British library.

It all began in 1975 when I met Ruth Melling, British librarian now in Colchester, England, who was an exchange librarian at the IndianaPurdue University campus at Fort Wayne. When I asked her how I might arrange a similar exchange, she explained that certain agencies involved in exchange programs for teachers would occasionally aid librarians, but their contacts with British libraries were inadequate. She suggested that I find someone in Britain who was interested and pursue it on my own.

My plan remained dormant until March, 1980, when I responded to an interlibrary loan inquiry from Margaret Dowling, ILL librarian at Edinburgh University Library. For some reason I was inspired to add a postscript that read: "Would you be interested in trading jobs for a year? If so, let me know. We may be able to work something out." Ms. Dowling very quickly wrote back saying she was interested. From that point it was a matter of 1) securing from our supervisors approval in principle, 2) exchanging resumes and information about our respective positions and libraries, and 3) pushing all of the paperwork for official approval through the bureaucratic process. This, along with negotiations for living accomodations and personal family matters, took a full year. A single person could easily speed up the process, but moving my family of four 4,000 miles required a great deal of logistic planning.

Apparently my fishing technique was a stroke of luck, for a colleague of mine has tried the approach several times with no result. British library administrators were often interested, but I met few librarians who were willing to trade jobs.
Family concerns and job security were the major reasons for their reluctance.

In my case most of the paperwork was done by us rather than by the university administration. Following an exchange of resumes and job descriptions the library administrators decided what position could be offered to each exchange person. It was not a direct exchange. At Edinburgh I took over Ms. Dowling's position which was changing because of reorganization. At Indiana my administrative position was filled temporarily with an experienced IU librarian, and Ms. Dowling was offered a position as a reference librarian in the Undergraduate Library. Each of us found the arrangement to be exactly what we were seeking. For me it was a year in which I got away from the demands of an administrative position and worked directly with users in reference and ILL. For Ms. Dowling it was an opportunity to broaden her experience by becoming actively involved in library instruction and undergraduate reference service, in contrast to her working primarily with faculty and graduate students at Edinburgh.

The librarian at the University of Edinburgh and the dean of libraries at Indiana University then agreed in writing to accept each other's librarians without pay and conform to the working conditions of the host library. Earlier it had been decided that the best way to arrange the exchange was for each of us to continue to be paid by the home institution and be sent "on assignment" to the host library. Any other arrangement would have required Edinburgh to provide considerable justification for a work permit for me, and it is very likely that it would have been denied-proving that I was more qualified for a reference and ILL position than 3 million unemployed British citizens is not an easy task!

At Indiana approval by the dean of faculties, the vice president for academic affairs, the president, and the board of trustees was necessary. Similar arrangements had already been made for teaching faculty, so that once the dean's office found the appropriate procedure, it was a matter of moving the paperwork through the right channels. 